\title{
Müzik Eğitimi Anabilim Dalı Öğrencilerinin Müzik Öğretmenliğini Tercih Etme Nedenlerinin Belirlenmesi
}

DOI: 10.26466/opus.675302

$*$

Riza Akyürek *

* Dr.Öğr.Üy., Muğla Sıtkı Koçman Üni.,Eğitim Fak., Güzel Sanatlar Eğitimi Böl., Müzik Eğitimi ABD. E-Posta: rizaakyurek@mu.edu.tr

ORCID: $\underline{0000-0001-6493-4871}$

Öz

Mesleki anlamda öğretmenlik toplum tarafından seçkin bir konumda yer alan saygın bir meslek grubu kategorisinde değerlendirilmektedir. Eğitimin geçmişten günümüze kadarki süreçte toplumlarm değişiminde, dönüşümünde ve gelişiminde öncü rol oynamaktadır. Öğretmenlik; bilgi ve becerilerin yanı sıra tutum ve düzenli alışkanlıkları da gerektiren bir meslektir. Bu araştırma, müzik eğitimi anabilim dalı öğrencilerinin müzik öğretmenliğini tercih etme nedenlerinin ve bu nedenlerin cinsiyet, yaş, sinıf ve mezun olunan lise değişkenlerine göre farklllı gösterip göstermediğinin belirlenmesini amaçlayan ilişkisel tarama modelinin kullanıldığ betimsel bir çalışmadır. Araştırmaya veri sağlamak amactyla öğretmenlik mesleği tercih nedenleri anketi kullanılmıştır. Araştırmaya Müzik Eğitimi Anabilim Dalı'nda öğrenim gören 110 öğrenci katılmıştır. Anket verileri tablolar halinde sunulmuş, cinsiyet, sınıf ve mezun olunan lise değişkenleri ile tercihleri arasında anlamlı ilişki olup olmadığııın belirlenmesine yönelik bağımsız örneklem $t$ testi ve tek faktörlü Varyans analizi (Anova) uygulanmıştır. Araştırma sonucunda Müzik Eğitimi Anabilim Dalı öğrencilerinin müzik öğretmenliğini tercih nedenleri ile cinsiyet ve mezun oldukları lise türlerine göre aralarında anlamlı bir farklılık olmadığı, sınıf değişkenine göre anlamlı farklılık olduğu sonuçlarına ulaşılmıştır. Ayrıca Müzik öğretmenliği tercihlerini bilinçli şekilde yaptıkları, herhangi bir ekonomik beklentilerinin olmadığı, tercihlerinde sosyal güvence imkânını kısmen göz önünde bulundurdukları, üniversitede başka herhangi bir bölümü tercih etmeyi düşünmedikleri sonuçlarına da ulaşılmıştır.

Anahtar Kelimeler: Müzik öğretmenliği, öğretmenlik tercih nedenleri, mesleki tercihler, müzik eğitimi 


\title{
Determination of the Reason of Preference to Music Teaching Students on Department of Music Education
}

\begin{abstract}
Professional teaching is considered by the community in a prestigious professional group category. It plays a leading role in the change, transformation and development of societies in the process of education from past to present. Teaching; It is a profession that requires attitudes and regular habits as well as knowledge and skills. This research is a descriptive study using the relational screening model, which aims to determine the reasons why students of music education department preference to music teaching and whether these reasons differ according to gender, age, class and graduated high school variables. In order to provide data for the research, a questionnaire for teaching profession reasons was used. 110 students were participating in this study in the Department of Music Education. Survey data are presented in tables, independent sample $t$ test and one-factor analysis of variance (Anova) were applied to determine whether there is a significant relationship between gender, class and graduated high school variables and their preferences. As a result of the research, it has been concluded that there is no significant difference between the students of Music Education Department according to their reasons for choosing music teaching, and gender and high school types they graduated, and there was a significant difference according to the class variable. In addition, it was concluded that they made their consciousness of music teacher preferences, they did not have any economic expectations, they considered the possibility of social security in their preferences, and that they did not intend to choose any other department in the university.
\end{abstract}

Keywords: Music teaching, preferred teaching, vocational preference, music education 


\section{Giriş}

Eğitim; kişinin zihni, bedeni, duygusal toplum yeteneklerinin, davranışlarının istenilen doğrultuda geliştirilmesi ya da ona birtakım amaçlara dönük yeni yetenekler, davranışlar, bilgiler kazandırılması yolundaki çalışmaların tümüdür. (Akyüz, 2013).

Genel olarak müzik eğitimi verilen kurumlar ilköğretim, ortaöğretim ve lisans olarak gösterilebilir. Bu kurumlarda verilen müzik eğitimi kişide temel olarak birtakım müziksel bilgi, kültür ve davranış kazandırmayı amaçlamaktadır. Müzik eğitimi, kısaca müziksel davranış kazandırma, müziksel davranış değiştirme ya da müziksel davranış geliştirme sürecidir. (Uçan, 2005). Müzik eğitimi, yönelik olduğu ana amaç ve kitle bakımından, kendi içinde üç ana türe ayrılır. Bunlar; genel - özengen (amatör) ve mesleki (profesyonel) müzik eğitimidir (Uçan, 1994). Genel müzik eğitimi, müzikle ilişkisi her ne olursa olsun herkes için gereklidir ve herkese yöneliktir.

Özengen müzik eğitimi, müziğe özel ilgisi, isteği ve yatkınlı̆ı olup müziği kendisi için bir düşkü (hobi) alanı olarak seçenlere yöneliktir. Mesleki müzik eğitimi, müzik alanının bütününü, bir kolunu ya da dalını, o bütün kol ya da dal ile ilgili bir işi meslek olarak seçen, seçmek isteyen, seçme eğilimi gösteren, seçme olasılığı bulunan ya da öyle görünen, müziğe belli düzeyde yetenekli kişilere yönelik olup, dalın, işin ya da mesleğin gerektirdiği müziksel davranışları ve birikimi kazandırmayı amaçlar (Uçan, 1997).

Eğitim süreci içinde öğrencilerin ilgi, eğitim ve yetenekleri doğrultusunda, aynı zamanda ülkenin ihtiyaç ve koşulları da dikkate alınarak, üst öğrenime, belli eğitim ve meslek alanlarına yönlendirilmeleri rehberlik hizmetlerinden beklenen en önemli işlev olmuştur. (Yeşilyaprak, 2005). Beklentiler; sayg1, esneklik, açık fikirlilik, risk alma, merak, görev bilinci vb... özellikleri beraberinde barındırır. Öğretmenler, öğrencilere sınıfta güçlü bir şekilde bu beklentiler doğrultusunda özerklik tanımakta ve eğitimi etkili bir hale getirmektedirler. (Parrott ve dgr. 2013).

Öğretmenlik mesleğini seçecek olan bireylerin önce yetenek, ilgi, değer ve kişilik özelliklerinin test ve test dişı tekniklerle belirlenmesi gerekir. Sonra öğretmenlik mesleğinin gerektirdiği ilgi, yetenek, değer ve diğer kişisel özelliklerin belirlenmesi gerekiyor. Bireyden ve öğretmenlik mesleğinden elde edilen bu bilgiler karşılaştırıldığında; kişilik özellikleriyle mesleğin gerektirdiği özellikleri binişiklik gösterenler seçilip, öğretmen yetiştiren 
kurumlara yerleştirilmelidirler (Övet, 2006). Günümüzde öğretmenlik mesleği, eğitim sektörü ile ilgili olan, sosyal, kültürel, ekonomik, bilimsel ve teknolojik boyutlara sahip alanlarda özel uzmanlık bilgi ve becerisinin temel alan akademik çalışma ve mesleki formasyonu gerektiren, profesyonel statüde bir uğraşı alanıdır (Alkan ve Hacıŏ̆lu, 1997). Öğretmenlik; bilgi ve becerilerin yanı sıra tutum ve düzenli alışkanlıkları da gerektiren bir meslektir. Bu nedenle öğretmen adaylarının meslekle ilgili değer ve tutum kazanmaları da, en az bilgi kadar gereklidir (Çeliköz ve Çetin, 2004). Öğretmenlerin mesleki verimliliklerini etkileyen önemli bir bileşen ise onların öğretmenlik mesleğini tercih nedenleri veya diğer bir deyişle öğretmen olmaya yönelik motivasyonlarıdır (Bruinsma ve Jansen, 2010).

Öğretmen adaylarının meslek tercihleri başlıca üç temel kategorideki etkenlere dayalıdır. Özgeci (özveriye dayalı) gerekçeler; insanlara hizmet etme arzusu, topluma faydalı olma isteği, ülkeye hizmet etmek. İçsel gerekçeler; mesleği sevmek, çocukları sevmek, insanları sevmek, ilgi duymak, yetenekli olduğunu düşünmek. Dışsal gerekçeler; iş garantisi, uzun tatil, sosyal güvence, atanma koşulları vb. olarak ifade edilmiştir (Saban,2003). Öğretmen adaylarının öğretmenlik mesleğini tercih etme nedenleri ve mesleki geleceklerine ilişkin motivasyonları onların lisans eğitimlerini, sonraki mesleki performanslarını ve bu yolla gelecekteki öğrencilerinin başarısını etkileme gücüne sahiptir (Atav ve Altunoğlu, 2013).

Her meslekte bulunması gereken bazı temel özellikler vardır. “Öğretmenlikte de en az diğer profesyonel meslekler gibi temel bazı özelliklerin bulunması gerektiği bugün az gelişmiş ülkelerde dahi kabul edilmiş bir gerçek olduğu gözlenmektedir. Öğretmen yetiştirme programlarına seçilecek adayların ilgi, yetenek ve isteklerinin göz önüne alınması, kalite ve verim bakımından önemlidir. Çünkü bireyin belli bir meslekte başarılı olması, onun mesleğe ilişkin yeterliklere sahip olup olmaması ile yakından ilişkilidir. (Çoban, 2004).

Meslek seçimi açısından bir kişinin kendini tanıması, onun meslek seçiminde rol oynayan kişilik özellikleri yönünden kendini açık ve doğru biçimde değerlendirebilmesidir. Başka bir deyişle; kişinin her istediğini bilmesi ve isteklerine erişebilme gücünü iyi tanıması gerekir. Yani hangi alanda ne düzeyde yeteneğe sahip olduğunu (Yetenek), Nasıl bir çalışma ortamında ne gibi işleri yapmaktan hoşlanacağını (İlgi), Mesleğinden ne gibi yararlar beklediğini (Değer) bilmesi gerekir (Övet, 2006). 


\section{Yöntem}

\section{Araștırmanın Modeli}

Bu araştırma, müzik eğitimi anabilim dalı öğrencilerinin müzik öğretmenliğini tercih etme nedenlerinin ve bu nedenlerin cinsiyet, yaş, sinıf ve mezun olunan lise değişkenlerine göre farklılık gösterip göstermediğinin belirlenmesini amaçlayan ilişkisel tarama modelinin kullanıldığı betimsel bir çalışmadır. İlişkisel araştırma deseni iki veya daha fazla değişkenlerin arasındaki ilişkiyi belirlemek için kullanılır (McMillan ve Schumacher, 2010). Bu çalışmada, Müzik eğitimi anabilim dalı öğrencilerinin müzik öğretmenliğini tercih etme nedenlerinin belirlenmesi, tercih nedenlerindeki etken faktörlerin ortaya çıkarılması ve öğretmenlik mesleği ile müzisyenlik arasındaki tercih ilişkilerinin belirlenmesi amaçlanmıştır.

\section{Çalışma Grubu}

Müzik eğitimi anabilim dalı ögrencilerinin öğretmenlik mesleğini tercih etme nedenlerinin belirlenmesinin amaçlandığı araştırmanın çalışma grubu Muğla Sıtkı Koçman Üniversitesi, Eğitim Fakültesi, Güzel Sanatlar Eğitimi Bölümü, Müzik Eğitimi Anabilim Dalı'nda 2019-2020 eğitim-öğretim yılı güz yarıyılında öğrenim gören 1.2.3. ve 4. öğrencilerinden oluşan toplam 110 müzik öğretmeni adayından oluşmaktadır. Ankete katılan öğrencilere ait kişisel bilgiler Tablo 1'de verilmektedir.

Tablo 1. Araştırmaya katılan öğretmen adaylarnın cinsiyet değişkenine göre dağılımları

\begin{tabular}{llll}
\hline Değişkenler & & $\mathbf{n}$ & $\mathbf{\%}$ \\
\hline \multirow{3}{*}{ Cinsiyet } & Kadın & 70 & $\mathbf{6 4}$ \\
\cline { 2 - 4 } & Erkek & 40 & $\mathbf{3 6}$ \\
\cline { 2 - 4 } & Toplam & $\mathbf{1 1 0}$ & $\mathbf{1 0 0}$ \\
\hline
\end{tabular}

Tablo 1 incelendiğinde araştırmaya katılan müzik öğretmeni adaylarının \% 64'ü kadın, \%36'sı erkektir. 
Tablo 2. Araştırmaya katılan öğretmen adaylarının sını değişkenine göre dağılımları

Değişkenler

Sinif

\begin{tabular}{lll} 
& $\mathbf{n}$ & $\mathbf{\%}$ \\
\hline 1.sinif & 37 & $\mathbf{3 3}$ \\
\hline 2 sinif & 24 & $\mathbf{2 2}$ \\
\hline 3.sinif & 24 & $\mathbf{2 2}$ \\
\hline 4. sinif & 25 & $\mathbf{2 3}$ \\
\hline Toplam & $\mathbf{1 1 0}$ & $\mathbf{1 0 0}$ \\
\hline
\end{tabular}

Tablo 2'ye göre ankete katılan öğrencilerin \%33'ü 1.sınıf, \%22'si 2.sınıf, \%22'si 3.sınıf ve \% 23'̈̈ 4.sınıf öğretmen adaylarından oluşmaktadır.

Tablo 3. Araştırmaya katılan öğretmen adaylarnnı aylık gelir düzeyi değişkenine göre dă̆ılımları

\begin{tabular}{llll}
\hline Değişkenler & & $\mathbf{n}$ & $\mathbf{\%}$ \\
\hline \multirow{4}{*}{ Aylık Gelir Düzeyi } & 400TL'den daha az & 11 & $\mathbf{1 0}$ \\
\cline { 2 - 4 } & 400TL-699TL & 22 & $\mathbf{2 0}$ \\
\cline { 2 - 4 } & 700TL-999TL & 32 & $\mathbf{3 0}$ \\
\cline { 2 - 4 } & 1000TLve üzeri & 45 & $\mathbf{4 0}$ \\
\cline { 2 - 4 } & Toplam & $\mathbf{1 1 0}$ & $\mathbf{1 0 0}$ \\
\hline
\end{tabular}

Tablo 3'e bakıldığında ankete katılan öğretmen adaylarının \%10'u aylık 400TL'nin altında gelirle geçimini sağlamakta, \%20'lik dilim 400TL-699TL arası aylık gelir ile, \%30'u 700TL ile 999TL arası aylık gelir ile, \%40'lık dilimi ise $1000 \mathrm{TL}$ ve üzeri aylık gelir ile geçimini sağlamaktadırlar.

Tablo 4. Araştırmaya katılan öğretmen adaylarının yaş değişkenine göre dağılımları

\begin{tabular}{|c|c|c|c|}
\hline Değişkenler & & $\mathrm{n}$ & $\%$ \\
\hline \multirow{6}{*}{ Yaş } & $17-19$ & 46 & 42 \\
\hline & $20-22$ & 47 & 42 \\
\hline & $23-25$ & 14 & 13 \\
\hline & $26-28$ & 2 & 2 \\
\hline & 29-31 & 1 & 1 \\
\hline & Toplam & 110 & 100 \\
\hline
\end{tabular}

Tablo 4'e bakıldığında ankete katılan öğrenciler ağırlıklı olarak 17-19 ve 20-22 yaş aralığındadır (\%42). Öğretmen adaylarının \%13'lük dilimi 23-25 yaş aralığında, \%2'lik oranda 26-28 yaş aralığı ve \%1 oranında 29-31 yaş aralığındadır. 


\section{Verilerin Toplanması}

Araştırma kapsamında müzik öğretmeni adaylarının öğretmenlik mesleği tercih nedenlerinin belirlenmesine yönelik verilerin toplanması amaciyla Övet (2006) tarafından hazırlanan, "Öğretmenlik Mesleği Tercih Nedenleri Anketi" kullanılmıştır. Anket kişisel bilgi formu ve öğretmenlik tercih nedenlerinin yer aldığı iki bölümden oluşmaktadır. Ankette Tamamen katılıyorum (5), Büyük ölçüde katılıyorum (4), Kısmen katılıyorum (3), Çok az katılıyorum (2) ve Hiç katılmıyorum (1) seçeneklerinin yer aldığı beşli likert tipi ölçek kullanılmıştır. Övet (2006) tarafından geliştirilen öğretmen adaylarının öğretmenlik mesleği tercih nedenleri anketine ait maddelerin faktör analizlerine göre; \% 32,064 açıklayıcllı̆ga sahip birincisine "Bilinç", \%10,972 açıklayıcılığa sahip ikincisine "Güvence", \%9,701 açıklayıcılığa sahip üçüncüsüne "İdeal", \% 8,451 açıklayıcilığa sahip dördüncüsüne "Etkilenme" alt madde isimlerini vermiştir. Anketin geçerlik ve güvenirliğini belirlemek amaçlı yapılan analiz sonucunda Cronbach Alpha değeri 0.8640 olarak hesaplanmiştır.

\section{Verilerin Çözümlenmesi}

Verilerin analizinde SPSS 11.5. programı kullanılmıştır. Müzik öğretmeni adaylarının öğretmenlik mesleğini tercih nedenlerinin cinsiyet ve mezun olunan lise türü değişkenlerine göre anlamlı farklılık olup olmadığının belirlenmesi için bağımsız örneklem $\mathrm{t}$ testi kullanılmış, öğretmenlik mesleği tercih nedenleri ile sınıf ve aylık gelir düzeyi değişkenleri arasında anlamlı fark olup olmadığının belirlenmesi için Tek Faktörlü Varyans Analizi (Anova) kullanılmıştır. Araştırma verilerinin yüzde ve frekans değerleri de hesaplanarak tablolar halinde sunulmuştur.

\section{Bulgular ve Yorumlar}

Tablo 5'e göre öğretmenlik meslek tercih anketi Bilinç alt boyutu betimsel istatistiklere bakıldığında öğretmen adaylarının \%60'ı müzik öğretmenliğini yapabileceği en uygun meslek olarak görürken bir başka soruda \%86'lik oranla müzik öğretmenliğini tesadüfen seçmediklerini belirtmişlerdir. Yine bir başka bulguda öğretmen adaylarının müzik öğretmenliğini sadece üni- 
versite okumak için seçmediklerini beyan etmektedirler. Adı geçen bulgular öğrencilerin müzik öğretmenliği tercihlerini bilinçli, isteyerek ve tamamen daha önceden planlanmış şekilde tercih ettiklerini göstermektedir.

Tablo 5. Öğretmenlik meslek tercih anketi Bilinç alt boyutuna ait frekans yüzde dağılımlar

\begin{tabular}{|c|c|c|c|c|c|c|c|c|c|c|c|}
\hline \multicolumn{2}{|c|}{$\begin{array}{l}\text { Öğretmenlik Meslek Tercih } \\
\text { Nedenleri Anketi }\end{array}$} & 5 & $\%$ & 4 & $\%$ & 3 & $\%$ & 2 & $\%$ & 1 & $\%$ \\
\hline \multirow{13}{*}{. } & $\begin{array}{l}\text { Müzik Öğretmenliğini } \\
\text { herkes tarafından } \\
\text { takdir edilen bir meslek } \\
\text { olduğu için seçtim. }\end{array}$ & 14 & 12,7 & 12 & 10,9 & 27 & 24,5 & 20 & 18,2 & 37 & 33,6 \\
\hline & $\begin{array}{l}\text { Müzik Öğretmenliği } \\
\text { yapabileceğim en } \\
\text { uygun meslek olduğu için seçtim. }\end{array}$ & 52 & 47,3 & 29 & 26,4 & 19 & 17,3 & 5 & 4,5 & 5 & 4,5 \\
\hline & $\begin{array}{l}\text { Müzik Öğretmenliğini } \\
\text { bana mutluluk vereceğine } \\
\text { inandı̆̆ım için seçtim. }\end{array}$ & 66 & 60 & 23 & 20,9 & 13 & 11,8 & 5 & 4,5 & 3 & 2,7 \\
\hline & $\begin{array}{l}\text { Müzik Öğretmenliğini } \\
\text { sadece üniversite okumak } \\
\text { için seçtim. }\end{array}$ & 1 & 0,9 & 3 & 2,7 & 3 & 2,7 & 15 & 13,6 & 88 & 80 \\
\hline & $\begin{array}{l}\text { Müzik Öğretmenliğini kendimi } \\
\text { geliştirebileceğim bir meslek oldu- } \\
\text { ğu için seçtim. }\end{array}$ & 59 & 53,6 & 29 & 26,4 & 10 & 9,1 & 7 & 6,4 & 5 & 4,5 \\
\hline & $\begin{array}{l}\text { Müzik Öğretmenliğini } \\
\text { bilinçli olarak seçtim. }\end{array}$ & 92 & 83,6 & 14 & 12,7 & 4 & 3,6 & 0 & 0 & 0 & 0 \\
\hline & $\begin{array}{l}\text { Müzik Öğretmenliğini herkes } \\
\text { tarafından yapllabilecek bir meslek } \\
\text { olmadığına inandığım ve özel } \\
\text { olduğumu } \\
\text { düşündünğüm için seçtim. }\end{array}$ & 50 & 45,5 & 26 & 23,6 & 20 & 18,2 & 5 & 4,5 & 9 & 8,2 \\
\hline & $\begin{array}{l}\text { Müzik Öğretmenliğini kişisel } \\
\text { amaçlarımı gerçekleştirebileceğim } \\
\text { bir meslek olduğu için }\end{array}$ & 46 & 41,8 & 29 & 26,4 & 24 & 21,8 & 3 & 2,7 & 8 & 7,3 \\
\hline & $\begin{array}{l}\text { Müzik Öğretmenliğini } \\
\text { tesadüfen seçtim. }\end{array}$ & 2 & 1,8 & 3 & 2,7 & 2 & 1,8 & 8 & 7,3 & 95 & 86,4 \\
\hline & $\begin{array}{l}\text { Müzik Öğretmenliğini } \\
\text { Eğitime katkıda bulunabileceğimi } \\
\text { düşündüğüm için seçtim. }\end{array}$ & 59 & 53,6 & 21 & 19,1 & 20 & 18,2 & 5 & 4,5 & 5 & 4,5 \\
\hline & $\begin{array}{lcc}\text { Müzik } & \text { Öğretmenliğini } & \text { mesleğin } \\
\text { gerektirdiği } & \text { yeteneklere } & \text { sahip } \\
\text { olduğumu } & \text { düşündüğüm } & \text { için } \\
\text { seçtim. } & & \\
\end{array}$ & 63 & 57,3 & 29 & 26,4 & 11 & 10 & 5 & 4,5 & 2 & 1,8 \\
\hline & $\begin{array}{l}\text { Müzik Öğretmenliğini sosyal yönü } \\
\text { güçlü bir meslek olduğu için seçtim. }\end{array}$ & 45 & 40,9 & 30 & 27,3 & 23 & 20,9 & 8 & 7,3 & 4 & 3,6 \\
\hline & $\begin{array}{l}\text { Müzik Öğretmenliğini } \\
\text { Ülkemizde Müzik Öğretmeni } \\
\text { ihtiyacının oldukça fazla } \\
\text { olduğunu düşündüğüm için }\end{array}$ & 24 & 21,8 & 19 & 17,3 & 33 & 30 & 12 & 10,9 & 22 & 20 \\
\hline
\end{tabular}


Tablo 6. Öğretmenlik meslek tercih anketi Güvence alt boyutuna ait frekans yüzde dağılımları

\begin{tabular}{|c|c|c|c|c|c|c|c|c|c|c|c|}
\hline \multicolumn{2}{|c|}{$\begin{array}{l}\text { Öğretmenlik Meslek Tercih } \\
\text { Nedenleri Anketi }\end{array}$} & 5 & $\%$ & 4 & $\%$ & 3 & $\%$ & 2 & $\%$ & 1 & $\%$ \\
\hline \multirow{5}{*}{ 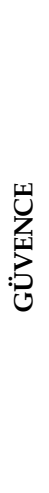 } & $\begin{array}{l}\text { Müzik Öğretmenliği'ni ekono- } \\
\text { mik olarak doyurucu } \\
\text { bulduğum için seçtim. }\end{array}$ & 5 & 4,5 & 10 & 9,1 & 21 & 19,1 & 24 & 21,8 & 50 & 45,5 \\
\hline & $\begin{array}{l}\text { Müzik Öğretmenliği'ni iş } \\
\text { güvencesi olduğu için seçtim. }\end{array}$ & 9 & 8,2 & 20 & 18,2 & 32 & 29,1 & 15 & 13,6 & 34 & 30,9 \\
\hline & $\begin{array}{l}\text { Müzik Öğretmenliği'ni } \\
\text { çalışma saatleri esnek olduğu } \\
\text { için seçtim. }\end{array}$ & 3 & 2,7 & 5 & 4,5 & 14 & 12,7 & 18 & 16,4 & 70 & 63,6 \\
\hline & $\begin{array}{l}\text { Müzik Öğretmenliği'ni mezun } \\
\text { olunca işimin hemen hazır } \\
\text { olacağı ümidiyle seçtim. }\end{array}$ & 15 & 13,6 & 17 & 15,5 & 33 & 30 & 15 & 13,6 & 30 & 27,3 \\
\hline & $\begin{array}{l}\text { Müzik Öğretmenliği'ni } \\
\text { sosyal güvencesi olduğu } \\
\text { için seçtim. }\end{array}$ & 16 & 14,5 & 14 & 12,7 & 28 & 25,5 & 27 & 24,5 & 25 & 22,7 \\
\hline
\end{tabular}

Tablo 6'daki öğretmenlik meslek tercih anketi güvence alt boyutuna ilişkin betimsel istatistikler incelendiğinde \%45.5 oranında müzik öretmeni adaylarının meslek tercihlerinde hiçbir ekonomik beklentinin olmadığı, \%63.6'lık oranda çalışma saatlerinin esnekliğinin hiçbir etkisinin olmadığı, kısmen iş beklentisinin ve sosyal güvence beklentilerinin öğretmen adaylarında mevcut olduğu bulguları göze çarpmaktadır.

Tablo 7. Öğretmenlik meslek tercih anketi İdeal alt boyutuna ait frekans yüzde dağılımlan

\begin{tabular}{lllllllllll}
\hline $\begin{array}{l}\text { Öğretmenlik Meslek Tercih } \\
\text { Nedenleri Anketi }\end{array}$ & $\mathbf{5}$ & $\mathbf{\%}$ & $\mathbf{4}$ & $\mathbf{\%}$ & $\mathbf{3}$ & $\mathbf{\%}$ & $\mathbf{2}$ & $\mathbf{\%}$ & $\mathbf{1}$ & $\mathbf{\%}$ \\
\hline $\begin{array}{l}\text { Müzik Öğretmenliği'ni idealim- } \\
\text { deki meslek olduğu için seçtim. }\end{array}$ & $\mathbf{6 6}$ & $\mathbf{6 0}$ & 22 & 20 & 11 & 10 & 8 & 7,3 & 3 & $\mathbf{2 , 7}$ \\
\hline $\begin{array}{l}\text { Müzik Öğretmenliği'ni üniver- } \\
\text { site snavinda istediğim başka } \\
\text { bölümlere puanım yetmediği } \\
\text { için seçtim. }\end{array}$ & $\mathbf{2}$ & $\mathbf{1 , 8}$ & $\mathbf{0}$ & $\mathbf{0}$ & $\mathbf{4}$ & $\mathbf{3 , 6}$ & $\mathbf{1 2}$ & $\mathbf{1 0 , 9}$ & $\mathbf{9 2}$ & $\mathbf{8 3 , 6}$ \\
\hline
\end{tabular}

Tablo 7'de müzik öğretmeni adaylarının mesleki tercihlerinde öğretmenliği yapabilecekleri ideal meslek olarak gördükleri için tercih ettikleri, üniversitede başka bölümleri düşünmedikleri bulguları görülmektedir. 
Tablo 8. Öğretmenlik meslek tercih anketi Etkilenme alt boyutuna ait frekans yïzde dağılımları

\begin{tabular}{|c|c|c|c|c|c|c|c|c|c|c|c|}
\hline \multicolumn{2}{|c|}{$\begin{array}{l}\text { Öğretmenlik Meslek Tercih } \\
\text { Nedenleri Anketi }\end{array}$} & 5 & $\%$ & 4 & $\%$ & 3 & $\%$ & 2 & $\%$ & 1 & $\%$ \\
\hline \multirow{8}{*}{ 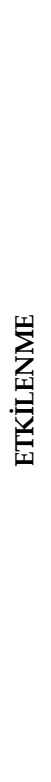 } & $\begin{array}{l}\text { Müzik Öğretmenliği'ni çevre- } \\
\text { min etkisiyle seçtim. }\end{array}$ & 10 & 9,1 & 12 & 10,9 & 18 & 16,4 & 25 & 22,7 & 45 & 40,9 \\
\hline & $\begin{array}{l}\text { Müzik Öğretmenliği'ni okul } \\
\text { hayatımdaki öğretmenlerim- } \\
\text { den etkilendiğim için seçtim. }\end{array}$ & 26 & 23,6 & 14 & 12,7 & 31 & 28,2 & 16 & 14,5 & 23 & 20,9 \\
\hline & $\begin{array}{l}\text { Müzik Öğretmenliği'ni Ailem } \\
\text { istediği için seçtim. }\end{array}$ & 6 & 5,5 & 7 & 6,4 & 15 & 13,6 & 24 & 21,8 & 58 & 52,7 \\
\hline & $\begin{array}{l}\text { Müzik Öğretmenliği'ni yakın } \\
\text { çevremden birisi Müzik Öğ- } \\
\text { retmeni olduğu için seçtim. }\end{array}$ & 6 & 5,5 & 8 & 7,3 & 11 & 10 & 16 & 14,5 & 69 & 62,7 \\
\hline & $\begin{array}{l}\text { Müzik Öğretmenliği'ni Müzis- } \\
\text { yen olmak istediğim için } \\
\text { seçtim. }\end{array}$ & 51 & 46,4 & 29 & 26,4 & 11 & 10 & 11 & 10 & 8 & 7,3 \\
\hline & $\begin{array}{l}\text { Müzik Öğretmenliği'ni Öğret- } \\
\text { menlik mesleğinin kutsal bir } \\
\text { meslek olduğuna inandığım } \\
\text { için seçtim. }\end{array}$ & 50 & 45,5 & 29 & 26,4 & 15 & 13,6 & 6 & 5,5 & 10 & 9,1 \\
\hline & $\begin{array}{l}\text { Müzik Öğretmenliği'ni müziği } \\
\text { çok sevdiğim için seçtim. }\end{array}$ & 84 & 76,4 & 18 & 16,4 & 4 & 3,6 & 3 & 2,7 & 1 & 0,9 \\
\hline & $\begin{array}{l}\text { Müzik Öğretmenliği'ni } \\
\text { çocukları çok sevdiğim için } \\
\text { seçtim. }\end{array}$ & 29 & 26,4 & 21 & 19,1 & 31 & 28,2 & 11 & 10 & 18 & 16,4 \\
\hline
\end{tabular}

Tablo 8'e bakıldığında öğretmen adaylarının meslek tercihlerinde aile ya da yakın çevrelerinin pek etkili olmadığı görülmektedir. Bunun aksine müziği çok sevdikleri için ve müzisyen olmak istedikleri için müzik öğretmenliğini tercih ettikleri bulgularına ulaşılmaktadır.

Tablo 9. Öğretmenlik tercih anketi alt boyutlarnın cinsiyet değişkenine göre anlamlılık düzeyleri t testi sonuçlan

\begin{tabular}{|c|c|c|c|c|c|c|c|}
\hline Değ. & & & $\mathbf{n}$ & Ort. & S. & $t$ & $\mathrm{p}$ \\
\hline \multirow[t]{2}{*}{ Bilinç } & \multirow{2}{*}{ Cinsiyet } & $\mathrm{K} 1 \mathrm{z}$ & 70 & 46.057 & 6.248 & \multirow[t]{2}{*}{0,512} & \multirow[t]{2}{*}{0,610} \\
\hline & & Erkek & 40 & 45.375 & 7.482 & & \\
\hline \multirow[t]{2}{*}{ Güvence } & \multirow{2}{*}{ Cinsiyet } & $\mathrm{K}_{12}$ & 70 & 11.600 & 4.566 & \multirow[t]{2}{*}{0,499} & \multirow[t]{2}{*}{0,619} \\
\hline & & Erkek & 40 & 12.075 & 5.205 & & \\
\hline \multirow[b]{2}{*}{ İDEAL } & \multirow{2}{*}{ Cinsiyet } & $\mathrm{K}_{12}$ & 70 & 5.414 & 1.123 & \multirow[t]{2}{*}{1,292} & \multirow[t]{2}{*}{0,199} \\
\hline & & Erkek & 40 & 5.725 & 1.358 & & \\
\hline \multirow{2}{*}{ Etkilenme } & \multirow{2}{*}{ Cinsiyet } & $\mathrm{K} 1 \mathrm{z}$ & 70 & 25.157 & 5.266 & \multirow[t]{2}{*}{0,969} & \multirow[t]{2}{*}{0,335} \\
\hline & & Erkek & 40 & 24.125 & 5.562 & & \\
\hline
\end{tabular}


Tablo 9'da $t$ testi sonuçları incelendiğinde ankete katılan öğrencilerin cinsiyet değişkenleri ile müzik öğretmenliği mesleğini tercih etme durumlar1 ve buna bağlı Bilinç, Güvence, İdeal ve Etkilenme alt boyutlanı arasında istatistiksel olarak anlamlı bir fark saptanamamıştır ( $p>0.05$ ). Buna göre; Müzik öğretmeni adaylarının öğretmenlik mesleğini tercih etme nedenlerinin cinsiyetleri ile anlamlı bir ilişkisinin olmadığı söylenebilir. Ortalama değerlere bakıldığında; öğretmenlik mesleğini tercih etme durumlarına ait bilinç ve etkilenme alt boyutlarına ilişkin kadın öğretmen adaylarının erkek öğretmen adaylarına göre meslek tercihlerinde daha bilinçli ve etki altında tercih yaptıkları, bunun yanında güvence ve ideal alt boyutları ortalamalarına bakıldığında ise erkek öğretmen adaylarının kadın öğretmen adaylarına göre mesleki tercihlerinde güvence ve idealist yaklaşımları ön planda tuttukları söylenebilir.

Tablo 10. Öğretmenlik tercih anketi alt boyutlarnın mezun olunan Lise türü değişkenine göre anlamlilık düzeyleri t testi sonuçları

\begin{tabular}{|c|c|c|c|c|c|c|}
\hline & & $\mathbf{N}$ & Ort. & St.S & $\mathrm{T}$ & I \\
\hline \multirow{2}{*}{ Bilinç } & GSL & 85 & 45.071 & 6.618 & & \\
\hline & Diğer & 25 & 48.320 & 6.473 & 2,168 & 0,032 \\
\hline \multirow{2}{*}{ Güvence } & GSL & 85 & 11.800 & 4.770 & & \\
\hline & Diğer & 25 & 11.680 & 4.956 & 0,110 & 0,913 \\
\hline \multirow{2}{*}{ İdeal } & GSL & 85 & 5.541 & 1.278 & & \\
\hline & Diğer & 25 & 5.480 & 1.005 & 0,221 & 0,826 \\
\hline \multirow{2}{*}{ Etkilenme } & GSL & 85 & 24.847 & 5.545 & & \\
\hline & Diğer & 25 & 24.560 & 4.840 & 0,234 & 0,816 \\
\hline
\end{tabular}

Tablo 10'daki $\mathrm{t}$ testi sonuçlarına göre ankete katılan öğrencilerin mezun oldukları Lise türü (Güzel Sanatlar Lisesi- Güzel Sanatlar dışındaki Liseler) değişkenleri ile müzik öğretmenliği mesleğini tercih etme durumları ve buna bağlı Güvence, İdeal ve Etkilenme alt boyutları arasında istatistiksel olarak anlamlı bir fark saptanamamıştır ( $p>0.05)$. Ankete katılan öğrencilerin mezun oldukları Lise türü (Güzel Sanatlar Lisesi- Güzel Sanatlar dışındaki Liseler) değişkenleri ile müzik öğretmenliği mesleğini tercihleri arasında Bilinç alt boyutuna ilişkin anlamlı bir farklılık olduğu tespit edilmiştir $(p<0,05)$. Buna göre; Güze Sanatlar Lisesi mezunu olmayan müzik öğretmeni adaylarının Güzel Sanatlar Lisesi mezunu müzik öğretmeni adaylarına göre öğretmenlik mesleğini daha bilinçli tercih ettikleri söylenebilir. 
Tablo 11. Öğretmenlik tercih anketi alt boyutlarnın sınıf değişkenine göre anlamlılık diizeyleri Anova testi sonuçlan

\begin{tabular}{|c|c|c|c|c|c|c|c|}
\hline & & & $\mathrm{n}$ & Ort. & St.S & $F$ & $p$ \\
\hline \multirow{4}{*}{ BİLINCÇ } & \multirow{4}{*}{ Sinif } & 1.Sinif & 37 & 2,27 & 1,28 & \multirow{4}{*}{3,714} & \multirow{4}{*}{0,014} \\
\hline & & 2. Sinif & 24 & 2,29 & 1,16 & & \\
\hline & & 3.Sinif & 24 & 3,29 & 1,30 & & \\
\hline & & 4.Sinif & 25 & 2,68 & 1,31 & & \\
\hline \multirow{4}{*}{ GÜVENCE } & \multirow{4}{*}{ Sinif } & 1.Sinif & 37 & 1,08 & 0,49 & \multirow{4}{*}{4,261} & \multirow{4}{*}{0,007} \\
\hline & & 2. Sinif & 24 & 1,33 & 0,70 & & \\
\hline & & 3.Sinif & 24 & 1,21 & 0,41 & & \\
\hline & & 4.Sinif & 25 & 1,72 & 1,10 & & \\
\hline \multirow{4}{*}{ İDEAL } & \multirow{4}{*}{ Sinif } & 1.Sinif & 37 & 1,16 & 0,55 & \multirow{4}{*}{2,142} & \multirow{4}{*}{0,099} \\
\hline & & 2. Sinif & 24 & 1,04 & 0,20 & & \\
\hline & & 3.Sinif & 24 & 1,38 & 0,87 & & \\
\hline & & 4.Sinif & 25 & 1,48 & 0,91 & & \\
\hline \multirow{4}{*}{ ETKILLENME } & \multirow{4}{*}{ Sinif } & 1.Sinif & 37 & 1,24 & 0,59 & \multirow{4}{*}{4,935} & \multirow{4}{*}{0,003} \\
\hline & & 2. Sinif & 24 & 1,79 & 1,17 & & \\
\hline & & 3.Sinif & 24 & 2,33 & 1,49 & & \\
\hline & & 4.Sinif & 25 & 2,04 & 1,36 & & \\
\hline
\end{tabular}

Tablo 11'e göre ankete katılan öğretmen adaylarının sınıf değişkenleri ile müzik öğretmenliği mesleğini tercih etme durumları ve buna bağl İdeal alt boyutu arasında istatistiksel olarak anlamlı bir fark saptanamamıştır ( $\mathrm{p}>0.05)$. Müzik öğretmeni adaylarının öğretmenlik meslek tercihleri Bilinç, Güvence ve Etkilenme alt boyutları ile sınıf değişkenleri arasında anlamlı bir ilişki olduğu istatistiksel olarak saptanmıştır $(\mathrm{P}<0,05)$. Buna göre; ankete katılan 3. Sınıf öğrencilerinin meslek tercihini diğer sınıflara göre daha bilinçli yaptıkları söylenebilir. Yine verilere bakıldığında ankete katılan 3 . ve 4. Sınıf öğretmen adaylarının 1. ve 2. Sınıf öğretmen adaylarına göre tercihlerini etkilenerek gerçekleştirdikleri bulgusuna ulaşılmıştır. Meslek tercihlerini yaparken 4. Sınıf öğretmen adaylarının diğer sınıflara göre tercihlerine iş güvencesinin etkili olduğu bulgusu da verilerde görülmektedir.

Tablo 12'deki veriler incelendiğinde ankete katılan öğrencilerin aylık gelir düzeyi değişkenleri ile müzik öğretmenliği mesleğini tercih etme durumları ve buna bağlı Bilinç, Güvence, İdeal ve Etkilenme alt boyutları arasında istatistiksel olarak anlamlı bir fark saptanamamıştır ( $p>0.05)$. Buna göre; Müzik öğretmeni adaylarının öğretmenlik mesleğini tercih etme nedenlerinin aylık gelir düzeyi ile anlamlı bir ilişkisinin olmadığı söylenebilir. 
Tablo 12. Öğretmenlik tercih anketi alt boyutlarnın aylık gelir düzeyi değişkenine göre anlamlilık düzeyleri Anova testi sonuçları

\begin{tabular}{|c|c|c|c|c|c|c|}
\hline & & $\mathbf{n}$ & Ort. & St.S & $\mathbf{F}$ & p \\
\hline \multirow[b]{4}{*}{ BİLINÇ } & 400TL'den daha az & 11 & 2,27 & 1,10 & \multirow{4}{*}{1,010} & \multirow{4}{*}{0,396} \\
\hline & 400TL-699TL aras1 & 22 & 3,00 & 1,15 & & \\
\hline & 700TL-999TL arası & 32 & 2,52 & 1,27 & & \\
\hline & 1000TL ve daha fazla & 45 & 2,52 & 1,45 & & \\
\hline \multirow[b]{4}{*}{ GÜVENCE } & 400TL'den daha az & 11 & 1,27 & 0,46 & \multirow{4}{*}{1,099} & \multirow{4}{*}{0,353} \\
\hline & 400TL-699TL aras1 & 22 & 1,27 & 0,55 & & \\
\hline & 700TL-999TL arası & 32 & 1,15 & 0,36 & & \\
\hline & 1000TL ve daha fazla & 45 & 1,45 & 1,02 & & \\
\hline \multirow[b]{4}{*}{ İDEAL } & 400TL'den daha az & 11 & 1,18 & 0,40 & \multirow{4}{*}{0,645} & \multirow{4}{*}{0,588} \\
\hline & 400TL-699TL arasi & 22 & 1,14 & 0,35 & & \\
\hline & 700TL-999TL arası & 32 & 1,21 & 0,54 & & \\
\hline & 1000TL ve daha fazla & 45 & 1,36 & 0,94 & & \\
\hline \multirow[b]{4}{*}{ ETKILLENME } & 400TL'den daha az & 11 & 1,55 & 0,82 & \multirow[b]{4}{*}{1,081} & \multirow[b]{4}{*}{0,361} \\
\hline & 400TL-699TL arasi & 22 & 2,14 & 1,42 & & \\
\hline & 700TL-999TL arasi & 32 & 1,85 & 1,30 & & \\
\hline & 1000TL ve daha fazla & 45 & 1,61 & 1,10 & & \\
\hline
\end{tabular}

\section{Sonuç Tartışma Ve Öneriler}

Müzik Eğitimi Anabilim Dalı'nda öğrenim gören müzik öğretmeni adaylarının öğretmenlik mesleği tercihleri yönlendiren, etkileyen faktörler incelendiğinde araştırma kapsamında aşağıdaki sonuçlara ulaşılmıştır;

Müzik öğretmeni adaylarının öğretmenliğini yapabileceği en uygun meslek olarak gördükleri, müzik öğretmenliğini tesadüfen seçmedikleri ve müzik öğretmenliğini sadece üniversite okumak için seçmedikleri, müzik öğretmenliği tercihlerini bilinçli, isteyerek ve tamamen daha önceden planlanmış şekilde tercih ettikleri belirlenmiştir. Nalçacı ve Sökmen (2016) araştırma sonucunda öğretmenlik tercihlerini birçok etkenin tetiklediğini fakat öğretmenlik tercihlerinin bilinçli şekilde ve daha önceden planlanarak gerçekleştirildiği sonuçlarına dikkat çekmektedirler.

Müzik öğretmeni adaylarının meslek tercihlerinde hiçbir ekonomik beklentinin olmadığı, çalışma saatlerinin esnekliğinin hiçbir etkisinin olmadığı, kısmen iş beklentisinin ve sosyal güvence beklentilerinin öğretmen adaylarında mevcut olduğu, mesleki tercihlerinde öğretmenliği yapabilecekleri en ideal meslek olarak gördükleri için tercih ettikleri, üniversitede başka bölümleri düşünmedikleri sonuçlarına ulaşılmıştır. 
Bir başka sonuca göre; öğretmen adaylarının meslek tercihlerinde aile ya da yakın çevrelerinin pek etkili olmadığı görülmektedir. Bunun aksine müziği çok sevdikleri için ve müzisyen olmak istedikleri için müzik öğretmenliğini tercih ettikleri belirlenmiştir.

Araştırma verilerinin istatistiksel çözümlemelerinde müzik öğretmeni adaylarının öğretmenlik mesleğini tercih etme nedenlerinin cinsiyetleri ile anlamlı bir ilişkisinin olmadığı sonucuna ulaşılmıştır.

Müzik öğretmeni adaylarının mezun oldukları Lise türü (Güzel Sanatlar Lisesi- Güzel Sanatlar Lisesi dişındaki Liseler) değişkenleri ile müzik öğretmenliği mesleğini tercih etme nedenleri ve buna bağlı Güvence, İdeal ve Etkilenme alt boyutları arasında istatistiksel olarak anlamlı bir farklılığa rastlanmamış, Mezun olunan Lise türü değişkenleri ile müzik öğretmenliği mesleğini tercihleri arasında Bilinç alt boyutuna ilişkin anlamlı bir farklılık olduğu tespit edilmiş, Buna göre; Güzel Sanatlar Lisesi mezunu olmayan müzik öğretmeni adaylarını Güzel Sanatlar Lisesi mezunu müzik öğretmeni adaylarına göre öğretmenlik mesleğini daha bilinçli tercih ettikleri sonucuna ulaşılmıştır.

Övet(2006) ve Merter (1996) araştırmalarında benzer sonuçlara ulaşmış, öğretmen adaylarının mesleki tercihlerini tamamen kendi istekleri doğrultusunda ve bilinçli olarak yaptıklarını, daha önceden planladıkları sonuçlarını tespit etmişlerdir. Övet yaptığı araştırmada kız öğrencilerin erkek öğrencilere oranla daha bilinçli tercih yaptıkları sonucuna ulaşmıştır.

Müzik öğretmeni adaylarının öğretmenlik meslek tercihleri Bilinç, Güvence ve Etkilenme alt boyutları ile sınıf değişkenleri arasında anlamlı bir ilişki olduğu istatistiksel olarak saptanmıştır. Buna göre; ankete katılan 3. Sınıf öğrencilerinin meslek tercihini diğer sınıflara göre daha bilinçli yaptıkları, 3. ve 4. Sınıf öğretmen adaylarının 1. ve 2. Sınıf öğretmen adaylarına göre tercihlerini etkilenerek gerçekleştirdikleri, meslek tercihlerinde 4. Sınıf öğretmen adaylarının diğer sınıflara göre iş güvencesinin etkili olduğu tespit edilmiştir.

Şimşek(2005), benzer araştırmasında araştırma benzer sonuçlara ulaşmış, öğretmenlik mesleği tercihlerinde hem iş güvencesi hem öğretmenin toplumdaki saygin statüsünün etkili olduğunu belirtmiştir.

Müzik öğretmeni adaylarının öğretmenlik mesleğini tercih etme nedenlerinin aylık gelir düzeyi ile anlamlı bir ilişkisinin olmadığı sonucuna ulaşılmıştır. 
Bu sonuçlar doğrultusunda aşağıdaki öneriler geliştirilmiştir;

- Müzik öğretmenliği mesleğine yönelecek öretmen adayları ilgili tercihleri doğrultusunda yönlendirilebilir, gerekli bilgilendirmeler yükseköğrenim öncesinde lise döneminde seminerler, sunumlar ve kılavuzlar hazırlanarak yapılabilir.

- Öğretmenlik mesleğinin toplumsal değeri ve saygınlığının daha da arttırılması konusunda ilgili bakanlıkça çalışmalar ve toplumun bakış açısinı arttırıc faaliyetler sıklıkla tekrarlanabilir.

- Teknolojinin gelişimi ve sosyal medyanın etkinliği göz önüne alındığında müzik öğretmenliği meslek tercihlerinin yaygın hale getirilmesi için hem görsel hem işitsel teknolojilerden daha fazla faydalanılabilir.

- Öğretmenlik meslek tercihlerinin daha bilinçli ve planlı hale gelmesi hususunda bireylerin, daha sonra ailelerin ve ilgili ortaöğretim kurumlarının eğitimin fakülteleri tarafından bilgilendirilmesi ve bilinçlendirilmesi sağlanabilir.

- Müzik öğretmenlerinin mesleki tercihlerini etkileyen faktörlerin araşttrıldığı bu ve benzeri çalışmalar desteklenebilir, çoğaltılabilir ve tercihlerde karşılaşılan olumsuzluklar bu tür bilimsel yaklaşımlarla giderilebilir. 


\title{
EXTENDED ABSTRACT
}

\section{Determination of the Reason of Preference to Music Teaching Students on Department of Music Education}

\author{
Rıza Akyürek \\ Muğla Sıtkı Koçman University
}

It plays a leading role in the change, transformation and development of societies in the process of education from past to present. Teaching; It is a profession that requires attitudes and regular habits as well as knowledge and skills. In the education process, the most important function expected from the guidance services is that the students are directed to higher education. There are some basic features that must be found in every profession. "It is observed that even in underdeveloped countries, it is an accepted fact that there should be some basic features such as at least other professional professions in teaching. Considering the interests, abilities and wishes of the candidates to be selected for teacher training programs is important in terms of quality and efficiency. The reasons for pre-service teachers' preference for teaching profession and their motivation for their professional future have the power to influence their undergraduate education, their subsequent professional performance and the success of their future students in this way. A person's self-knowledge in terms of choice of profession is his ability to evaluate himself clearly and correctly in terms of personality traits that play a role in the choice of profession. In other words; one must know what he wants and must know well the power to access his wishes. This research is a descriptive study using a relational screening model that aims to determine the reasons why students of music education department prefer music teaching and whether these reasons differ according to gender, age, class and graduated high school variables. The study group of the study, which aims to determine the reasons for the preference of the profession of music education students for teaching profession, is in the fall semester of 20192020 academic year in Muğla Sıtkı Koçman University, Faculty of Education, Department of Fine Arts Education, Department of Music Education. It consists of a total of 110 music teacher candidates consisting of 1-2-3-4th 
grades students. Within the scope of the research, "Teacher Profession Preference Reasons Questionnaire" prepared by Övet (2006) was used in order to collect data for determining the reasons for preference of teacher candidates for music teachers. The questionnaire consists of two parts including personal information form and reasons for preference for teaching. In the survey, a five-point Likert-type scale with the options of "I totally agree" (5) "I strongly agree" (4), "Partially agree" (3), "I agree very little" (2) and "Never agree" (1) For this survey was used SPSS 11.5 in the analysis of the data program. Independent sample $t$ test was used to determine whether the reasons for music teacher candidates choosing teaching profession differed according to gender and graduated high school type variables. Single Factor Variance Analysis (Anova) was used. Percentage and frequency values of the research data are also calculated and presented in tables. As a result of the research, music teacher candidates regarded as the most suitable profession that they could teach, they did not choose music teaching by chance and chose music teaching only for university education, music teacher candidates had no economic expectations in their professional preferences in their professional preferences, the flexibility of working hours has no effect, partly because job prospects and social security expectations are present in prospective teachers, they prefer it because they see it as the most ideal profession they can teach in their professional preferences, they do not think of other departments in the university, and their family or immediate environment is not very effective in their professional preferences. On the contrary, it is concluded that they prefer music teaching because they love music and want to be a musician. It was statistically determined that there is a significant relationship between the pre-service teachers' professional preferences Consciousness, Assurance and Influence sub-dimensions and classroom variables. The 3 rd grade students who participated in the questionnaire made their professional choices more conscious than other classes, and the 3rd and 4th grade pre-service teachers made their preferences according to the 1st and 2nd grade teacher candidates, and the job security of 4th grade pre-service teachers compared to other classes was effective. The result was revealed. In the light of these results, within the scope of the research; Candidate teachers who will turn to the profession of music teaching can be directed in line with their preferences, necessary informations can be made by preparing seminars, presentations and guides before high school, studies 
by the relevant ministry on increasing the social value and respectability of the teaching profession and activities that increase the perspective of the society can be repeated. Considering the development and the effectiveness of social media, both the visual and auditory technologies can be used more in order to popularize the profession of music teaching. Informing and raising awareness of individuals, then families and related secondary education institutions by the faculties of education in order to make the teaching profession preferences more conscious and planned. be influenced, to influence the professional preferences of music teachers These and similar studies in which $\mathrm{n}$ factors are explored can be supported, reproduced and the problems encountered in preferences can be overcome with such scientific approaches.

\section{Kaynakça / References}

Akyüz, Y. (1999). Türk eğitim tarihi. 7. Baskı. İstanbul: Alfa Basım Yayım Dağıtım

Alkan,C. ve Hacıŏglu, F.(1999).Öğretmenlik uygulamaları. Ankara: Alkım Yayınevi

Atav, E. ve Altunoğlu, B. D. (2013). Meslek ve alan seçiminde motivasyon ölçeğinin türkçe formunun geçerlik ve güvenirlik çalışması. Hacettepe Üniversitesi Ĕ̆itim Fakültesi Dergisi, 28, s.58-70.

Bruinsma, M., Jansen E. P. (2010). Is the motivation to become a teacher related to pre-service teachers' intentions to remain in the profession? European Journal of Teacher Education, 33, s.185-200.

Çeliköz, N., Çetin, F. (2004). Anadolu Öğretmen Lisesi öğrencilerinin öğretmenlik mesleğine yönelik tutumlarının etkileyen etmenler. Milli Eğitim Dergisi, 162, 136-145

Çoban, A. (2004). Öğretmen yetiştiren yükseköğretim kurumlarının kaynağ olarak anadolu öğretmen lisesi öğrencilerinin görüşlerinin değerlendirmesi. Cumhuriyet Üniversitesi Sosyal Bilimler Dergisi, 28(1), 55-64

Merter, F. (1996). Öğretmenlik mesleğinin geleceği ve statüsü eğitim fakültesi öğrencileri üzerine bir araştırma. Yeni Türkiye Dergisi Ĕ̆itim, 7, s.396-405.

McMillan, J.H. ve Schumacher, S. (2010). Research in education: Evidence-based inquiry (7th Edt.). London

Nalçacı, A. Sökmen, Y. (2016). Öğretmen adaylarının mesleği tercih nedenleri ve öğretmenlik mesleğine yönelik tutumları arasındaki ilişki. Ahi Evran Üniversitesi Kırşehir Eğitim Fakültesi Dergisi (KEFAD) 17(3), s.717-727. 
Övet, O. (2006). Eğitim fakültesi öğrencilerinin öğretmenlik mesleğini tercih etmelerinde etkili olan faktörlerin belirlenmesi. Yayımlanmamış Yüksek Lisans Tezi. Yeditepe Üniversitesi, Sosyal Bilimler Enstitüsü, İstanbul

Parrott, M., Da Ros-Voseles, D., ve Eaton, P. (2013). A picturesque view of dispositions, autonomy, and efficacy during the educational preparation of early childhood educators. Champaign, IL: ERIC Clearinghouse on Elementary and Early Childhood Curriculum. (ERIC Document Reproduction Service No. ED540356)

Saban, A. (2013). A Turkish profile of prospective elementary school teachers and their views of teaching. Teaching and Teacher Education, Elsevier Ltd.

Şimşek, H. (2005). Ortaöğretim alan öğretmenliği tezsiz yüksek lisans programina devam eden öğrencilerinin öğretmenlik mesleğine yönelik tutumları. Van Yüzüncü Yıl Üniversitesi, Eğitim Fakültesi Dergisi, 2(1), 19-37.

Uçan, A. (1994). G.Ü GEF müzik eğitimi bölümünün açılımları ve 2000'li yıllara doğru atılım projeleri. Ankara: Filarmoni Sanat Dergisi, 128.

Uçan, A. (1997). Müzik eğitimi. (2.Baskı). Ankara: Müzik Ansiklopedisi Yayınları.

Uçan, A. (2005). Müzik eğitimi temel kavramlar-ilkeler-yaklaşimlar ve Türkiye'deki durum. (Genişletilmiş 3. Basım). Ankara: Evrensel Müzikevi.

Yeşilyaprak, B. (2005). Eğitimde rehberlik hizmetleri gelişimsel yaklaşım. 12. Baskı. Ankara: Nobel Yayınları

\section{Kaynakça Bilgisi / Citation Information}

Akyürek, R. (2020). Müzik eğitimi anabilim dalı öğrencilerinin müzik öğretmenliğini tercih etme nedenlerinin belirlenmesi. OPUSUluslararası Toplum Araştırmaları Dergisi, 15(24), 2856-2874. DOI: 10.26466/opus.675302 